\title{
Constitutional Grounds for Questioning Elections in Nigeria: An Overview
}

\author{
F. O. Osadolor ${ }^{1}$ \\ ${ }^{1}$ Department of Public Law, Faculty of Law, University of Benin, Benin City, Nigeria \\ Correspondence: F. O. Osadolor, Department of Public Law, Faculty of Law, University of Benin, Benin City, \\ Edo State, Nigeria. E-mail: faith.osadolor@uniben.edu
}

Received: May 27, 2019

doi:10.5539/jpl.v12n3p167
Accepted: July 11, 2019 Online Published: August 30, 2019

URL: https://doi.org/10.5539/jpl.v12n3p167

\begin{abstract}
Periodic elections are major planks of democracy that has its attendant grievance procedure which ensures that the real consent of the governed is sort and obtained. The origination process in Nigeria is through election petitions, which is sui generis. The appropriate electoral statute and the constitution prescribe the grounds for questioning elections in Nigeria. The essence of this paper therefore is to resolve the apparent conflict as to where to predicate the grounds for questioning elections in Nigeria. Is it the Electoral Act, the Constitution or both in pursuit of electoral justice: Quo vadis?
\end{abstract}

Keywords: election petition, Federal Republic of Nigeria, independent electoral commission, substantial compliance, election petition tribunals

\section{Introduction}

Elections in Nigeria usually throws up volumes of election petitions, which question the validity of results declared by the Independent Electoral Commission (INEC), which is the body responsible for conducting elections in Nigeria. The petitioners in an election petition face several challenges resulting in majority of such petitioners failing for one reason or the other leaving the much majority that fails naturally disappointed with the decisions of the election tribunals. With particular focus on the grounds for questioning elections in Nigeria, this paper highlights the sui generis nature of election petitions.

The article argues that the grounds for contesting the validity of an electoral return in Nigeria, being spelt out in the constitution of the Federal Republic of Nigeria (CFRN) are not left to the discretion of the courts nor are they capable of being expanded or constricted by the brilliance of counsel or the prerogative of the judge. In summary, the article stresses that it is of utmost importance for a would-be petition to seriously consider their ground for intending to litigate an election result with a view to determining that the grounds arise from election properly so called and ipso facto fall within the purview of the jurisdiction of election petition tribunal.

We have shown that the grounds for questioning elections in Nigeria are quite clearly stated in the relevant provisions of the CFRN -239(11)(a) and section 285(1)(a) and (2) - and the Electoral Act - 138(1)(a)(b)(c) and (d). Beyond these, the courts are not entitled to look to no other piece of legislation. It is submitted that a petitioner can predicate his petition under the grounds stipulated in the Electoral Act or under the Constitution or both.

\section{Concept of Election}

To do justice to this topic, it is imperative that we understand "election" by definition. This is because, as we shall show later in the work, election petition in Nigeria is sui generis and relates only to an activity that clearly falls within the purview of election. Therefore, the jurisdiction of election petition tribunal and well as the decision to bring an election petition is first and foremost guided by the definition of election petition. This is because it is not all matters that arise from the electioneering processes that fall within the purview of election and consequently within the jurisdiction of election petition. Many of those matters are dealt with by the regular courts of the land as pre-election matters, which are usually very time sensitive in the sense that the aggrieved person must sue within a certain timeframe. By implication, if the aggrieved person erroneously interprets a matter that is properly pre-election matter as an election matter, the person will be clearly out of time by the time the election tribunal declines jurisdiction. 
Important as the definition of election is, the Electoral Act, 2011, is devoid of any meaningful definition of election as it defines election to mean any "election' held under this Act and includes a referendum". It is submitted that the above definition is at best literally begging the question as it relates to the definition of election. The Webster Illustrated Contemporary Dictionary, defines election as the selecting of a person or persons for office, as by ballot. Similarly, the Webster's New World Dictionary defines election simply as choosing or being chosen for office by vote.

It is pertinent to state that the Nigerian judiciary in a plethora of cases has defined election, irrespective of the lacuna in the successive Electoral Acts $^{2}$ to define election.

On the meaning of election within the context of section 137(1](b) of the Constitution of the Federal Republic of Nigeria, 1999, (CFRN), the Supreme Court, in the Ojukwu v. Obasanjo, ${ }^{3}$ stated that election means, "exercise of adult suffrage, which involves voters, materials for voting and supervision and counting of votes by electoral personnel." In particular, Edozie JSC defined word "election", in the context in which it is used in section 137 (1](b] of the 1999 Constitution, to mean the process of choosing, by popular votes, a candidate for a political office in a democratic system of government. ${ }^{4}$ The Court of Appeal relied on the above Supreme Court position in its definition of election in Peoples Progressive Alliance v. Dr Bukola Saraki, ${ }^{5}$ as the act of "choosing especially by voting". 6

In Independent National Electoral Commission v. Onimbah E.C. Ray \& Ors., ${ }^{7}$ the question was raised as to whether "election" refers to the whole process of election, constituting accreditation, voting, collating, recording on all relevant Independent National Electoral Commission forms and declaration of result; or, on the other hand, "election" refers to merely voting in units or wards as the case may be. On this score, Ogunbiyi JCA, reasoned that:

It is trite law that the concept of 'election' denotes a process constituting accreditation, voting, collation, recording on all relevant INEC forms and declaration of results. The collation of all results of the polling units making up the wards and the declaration of results are therefore constituent elements of an election as known to law. ${ }^{8}$

Similarly, in Adewale Segun Sunday \& Anor. v. Independent National Electoral Commission (INEC), ${ }^{9}$ Hussein Mukhtar, took an all-encompassing view of the word "election". According to his lordship, "election" is wider than "poll" and "election as a process cannot be divorced from the preliminary matters of sponsorship and nomination, just as polls, declaration of results and the issuance of certificates are an integral part of the process. They are all part of the whole". ${ }^{10}$ This wider concept of election has become well-established in the jurisprudence of Nigerian court on the subject. ${ }^{11}$

It appears obvious from the cases referred to above, that the failure of the Electoral Act and the CFRN, 1999 (as amended) to define election created a gap which needed to be filled by judicial pronouncements. Thankfully, the courts have risen up to the task to provide a working definition, given the fact that the sui generis nature of election petitions creates the imperative of a conceptual framework that houses all the components of elections so as not to unduly remove a matter that falls within the ambit of elections from the jurisdiction of election tribunals. It is equally important that the conceptual framework is not stated in very wide terms to include matters that ordinarily do not fall within the remit of elections.

Though the conceptualization of election by the different judicial authorities easily fills the gap, it is arguable

\footnotetext{
${ }^{1}$ Section 156 of the Electoral Act.

${ }^{2}$ Electoral Act 1962; Electoral (Amendment) Act 1964; Electoral (Amendment) Decree 1979; Electoral Act 2002; Electoral Act 2006; Electoral Act 2010, and Electoral Act 2010 (as amended).

${ }^{3}$ [2004] 1 LRECN, 481, 491.

${ }^{4}$ Ibid

5 [2007] LRECN, 138, 142, 159-160.

${ }^{6}$ Ibid., 142

${ }^{7}$ [2004] 14 NWLR pt. 892, 92.

${ }^{8}$ Ibid., 123

${ }^{9}$ [2008] 2 LRECN, 392, 411.

${ }^{10} \mathrm{Ibid}$

${ }^{11}$ See Kwara v. Innocent, [2009] 1 NWLR, pt. 1121, 179, 217; Independent National Electoral Commission (INEC) v. Comrade Adams Aliyu Oshiomole [2009] 4 NWLR, pt. 1132, 607, 662.
} 
that the definition of election by the Supreme Court in Ojukwu v. Obasanjo, ${ }^{12}$ is inchoate as it is limited to counting of votes by the electoral personnel. It is thus submitted that at the stage of counting of votes by the electoral personnel, election is inconclusive. It is therefore concluded only when the votes counted are collated, entered in the appropriate forms of the Independent National Electoral Commission, and ultimately the results therefrom are declared. Consequently, any definition of election devoid of the fundamental ingredients of collation, entry in the appropriate forms and ultimate declaration of results is inchoate. A working definition of election therefore must encapsulate the declaration of result.

\section{Concept of Petition}

It is worthy of note that the Electoral Act also failed to define or give any clear meaning to the word petition. Again, section 156 of the Act gave it the circuitous definition that says a "petition" means an election petition under the Act. It is also instructive to note that successive Electoral Acts, have also failed to give any credible meaning to the word petition. According to the Webster Illustrated Contemporary Dictionary, a petition is "a formal application in writing made to a court, requesting judicial action concerning some matter therein set forth". Similarly, the Webster's New World Dictionary defines petition as "a written request or plea in which specific court action is asked for". The Black's Law Dictionary defines a petition as "a formal written request presented to a court or other official body". It could be said from the foregoing, that a petition is a formal application in writing, presented to a court or tribunal, requesting judicial action in the matter therein set forth: It could therefore be an application to an election tribunal or court requesting judicial action as to the validity or otherwise of a candidate's return, when such return is allegedly invalid for non-compliance with the Electoral Act or specific constitutional stipulations. It is submitted that, section 133(1] of the Electoral Act, while prescribing the way and manner of questioning an election by the only mode admissible to the Act, described the nature of an election petition, thus:

No election and return of an election under this Act shall be questioned in any manner other than by a petition complaining of an undue election or undue return (in the Act referred to as an "election petition"] presented to the competent tribunal or court in accordance with the provisions of the constitution or of this Act and in which the person elected or returned is joined as a party.

The Court of Appeal in the case of All Nigeria Peoples Party v. Independent National Electoral Commission ${ }^{13}$ stated the constituents of an election petition thus to be a complaint by the petitioner against an undue election or return of a successful candidate at the election. It is not a complaint against INEC and its officers and agents who conducted the election, for failure to conduct the election as prescribed by law. The court further declared that the fact that the challenge of the election is the foundation of the cause of action in an election petition is also traceable to the provisions of the Constitution prescribing the jurisdiction of election tribunals created under the Constitution.

\section{Grounds as Basis for Questioning Elections in Nigeria}

Etymologically, what is the meaning of "ground"? According to the Webster Contemporary Dictionary, "ground", means "a sufficient cause, good reason, basis". The Black's Law Dictionary conceptualizes ground to mean, "the reason or point that something (as a legal claim or argument) relies on for validity, or to provide a basis for something such as a legal claim or argument. Webster's Comprehensive Dictionary also defines "ground" as "a starting point, good reason, basis, sufficient cause".

What can be deduced from the definitions above is that grounds for election petitions mean good reasons or basis for bringing an election petition before a tribunal. Ipso facto, grounds for an election petition are the basis of the petitioner's complaint against an election. It is submitted that grounds of election petitions are statutorily provided for. It is distillable from historical perspective that different electoral laws in Nigeria have provided different grounds upon which an election petition may be questioned. ${ }^{14}$

By virtue of the provisions of section 138(1) of the Electoral Act, an election may be questioned on any of the following grounds:

a. That a person whose election is questioned was at the time of the election, not qualified to contest the election;

12 [2009] 1 NWLR, (Pt. 1121), 179, 217.

13 [2004] 7 NWLR, 871, 16.

${ }^{14}$ See note 2, above 
b. That the election was invalid by reason of corrupt practices or non-compliance with the provisions of this Act;

c. That the respondent was not duly elected by majority of lawful votes cast at the election; or

d. That the petitioner or its candidate was validly nominated but was unlawfully excluded from the election.

The Electoral Act further provides in section 138(2) that:

An act or omission which may be contrary to an instruction or directive of the commission or of an officer appointed for the purpose of the election but which is not contrary to the provisions of the Act shall not of itself be a ground for questioning the election.

It is worthy of note that in addition to the four grounds for election petitions stated in section 138(1) of the Electoral Act, the Supreme Court, in Obasanjo v. Yusuf, ${ }^{15}$ unequivocally declared that the provisions of sections 239(1)(a) and 285(1)(a) \& (b) and (2) of the CFRN, created additional grounds for questioning the election of the President or the Vice-President, members of the National Assembly, or Governor or Deputy Governor or member of any state House of Assembly, respectively. Section 239 (1) (a) and Section 285 (1)(a) \& (b) and (2) of the Constitution provides:

Section 239:

(1) "Subject to the provisions of this Constitution, the Court of Appeal shall, to the exclusion of any other court of law in Nigeria, have original jurisdiction to hear and determine any question as to whether;

(a) Any person has been validly elected to the office of President or Vice-President under this constitution; or ..."

Section 285 provides:

(1) "There shall be established for each State of the Federation and the Federal Capital Territory, one or more election tribunals to be known as the National and State Houses of Assembly Election Tribunals which shall, to the exclusion of any Court or tribunal, have original jurisdiction to hear and determine petitions as to whether-

(a) Any person has been validly elected as a member of the National Assembly; or

(b) Any person has been validly elected as a member of the House of Assembly of a State.

(2) There shall be established in each State of the Federation an election tribunal to be known as Governorship Election Tribunal which shall, to the exclusion of any court or tribunal, have original jurisdiction to hear and determine petitions as to whether any person has been validly elected to the office of Governor or Deputy Governor.

In the case of Obasanjo v. Yusuf, ${ }^{16}$ the principal relief sought by the petitioner was for the Tribunal to hold that first Respondent was not duly or validly elected or returned as the President of the Federal Republic of Nigeria pursuant to the election held on the $19^{\text {th }}$ April, 2003. ${ }^{17}$

The Supreme Court held that the ground stated above was clearly within the ambit of section 239(1)(a) of the Constitution $^{18}$ and same was completely outside the four grounds stipulated in section 134(1) of the Electoral Act. ${ }^{19}$ The Court further declared that it was an act of good draftsmanship that the Electoral Act did not, by any stretch of imagination, repeat the provisions of section 239(1)(a) of the Constitution, as such a repeated provision would have been inoperative or at best mere surplusage. It is therefore the extant legal position that a petitioner may choose to come under the ground stipulated in the Constitution or under the Electoral Act. However, for complaints against a return or incompetency of election, such complaints must be cognizable either under the relevant provisions of the Constitution or the Electoral Act or both.

\footnotetext{
15 (2004) 9 NWLR pt. 877, 144.

16 (2004) 9NWLR, pt. 877, 144.

${ }^{17}$ Ibid.

${ }^{18}$ It was then the Constitution of the Federal Republic of Nigeria, 1999.

${ }^{19}$ The section 134(1) of the Act referred to is the Electoral Act, 2002, which is in pari material with section 138(1) of the Electoral Act, 2010 (as amended).
} 
In the case of Yusuf v. Obasanjo, ${ }^{20}$ paragraphs in a petition against the election of the President headed "fundamental unconstitutionalities as to campaign finance" and "fundamental illegal canvassing for votes" were respectively held to amount to infractions of the Constitution and Companies and Allied Matters Act and Collateral Issues over which the Presidential Election Tribunal had jurisdiction by virtue of sections 131-134 of the Electoral Act. ${ }^{21}$ To put it within the context of the point made above in respect to the importance of a proper definition of "election", these additional grounds for challenging election results can correctly be said to now fall within the definition of election.

In the case of Ogboru v. Ibori, ${ }^{22}$ the Court held that section 134 of the Electoral $\mathrm{Act}^{23}$ did not make "irregularities" one of the grounds for contesting an election. The word "irregularities" was in this case categorically distinguished from corrupt practices or non-compliance, which was one of the specific grounds set out in the section. Against this background, paragraph 4 of the petition that questioned the election on the ground of "irregularities" was held to be unknown to the Electoral Act, and consequently struck out.

The case of Adeloye v. Oviolola, ${ }^{24}$ also bears on the issue. In the case, the Appellant and the $1^{\text {st }}$ Respondent contested as councillorship candidates of different parties of which $1^{\text {st }}$ Respondent, who contested under the All Peoples Party (APP) emerged victorious at the election. The Appellant, who was the candidate of the Peoples Democratic Party (PDP), brought a petition that questioned the validity of the nomination of the first Respondent by the All Peoples Party (APP). The Counsel to the Respondent filed a preliminary objection to the competence of the petition. One of the grounds of the preliminary objection was that the issue of the validity of the nomination of the first Respondent was outside the purview of the grounds of election petition encapsulated in section 84(1) of the Local Government (Basic Constitutional and Transitional Provisions) Decree. ${ }^{25}$ The Court of Appeal had no difficulty confirming the decision of the Tribunal that struck out the petition for incompetence. According to the Court of Appeal:

Having examined closely the grounds upon which the Appellant challenged the election of the first Respondent in paragraph 10 of the petition, I entirely agree with the tribunal that those grounds are not in line with the grounds specified under the Decree above for challenging an election, as most of the complaints of the Appellant relate to matters that took place even before the election of $5^{\text {th }}$ December, 1998... it is the law that it is the nature of the action before the Court or tribunal that determines whether or not the Court or tribunal can entertain the action. See Okonma v. Nwaegbu (1992) 2NWLR (Pt255), 622 and Alese v. Aldetuyi (1995) NWLR (Pt403), 527. In the present case therefore, the tribunal having found that the grounds upon which the Appellant's petition was based were not in accordance with the law, the tribunal was duly bound to bring the proceedings in the petition to an end and no matter at what stage the proceedings were.

The case of Nwabodu v. Giff ${ }^{26}$ also demonstrated beyond doubt, that no petition before a tribunal is competent, except same is predicated on the grounds stated in the Electoral Act and the Constitution or both. In this case, the petitioner, a candidate of the Democratic Party of Nigeria (DPN), was recorded to have scored a majority of votes as against the $1^{\text {st }}$ Respondent. However, irrespective of the aforesaid record, the $1^{\text {st }}$ Respondent was declared elected instead of the petitioner on the ground that the petitioner had been disqualified by the second Respondent, the electoral body, two days before the election. The petitioner filed a petition contending that he had no notice of his disqualification or the reason for it and therefore the disqualification was invalid. While striking out the petition with judicial ease, the Court of Appeal construed section 89(1) of the Local Government (Basic Constitutional and Transitional Provisions) Decree No 7 of 1997, and Ipso facto held that none of the grounds applied to the case, since the petitioner actually took part in the election but lost to the first Respondent, though the latter was recorded to have scored lesser votes. The Court, speaking through Nsofor JCA held:

As the law stands, it does not appear the present petitioner may present an election

\footnotetext{
${ }^{20}$ (2005) 18 NWLR pt. 959, 96.

${ }^{21}$ The Electoral Act referred to in this case was the Electoral Act, 2002.

${ }^{22}$ (2004) 7 NWLR, pt. 871, 192.

${ }^{23}$ The Electoral Act referred to in this case, was the Electoral Act, 2002 section 134 of the Electoral Act, 2002 is in pari material with section 145 of the Electoral Act, 2006 and section 138 of the Electoral Act, 2010 (as amended).

${ }^{24}$ (1999) 4 NWLR, pt. 598, 273.

${ }^{25}$ Decree No 36 of 1998.

${ }^{26}$ (1998) 12 NWLR, pt. 579, 522.
} 
petition under any of the grounds stated in section 89(1) of the Decree No 7 of 1997. His remedy may be elsewhere. What has happened may have been beyond the contemplation of the legislation in question. ${ }^{27}$

It is arguable that this case highlights the possibility of occasions arising in which a petitioner suffe 3 rs injustice for being unable locate the ground(s) of their petition on any of the cognizable grounds of the electoral act or the constitution.

The case of Ojiegbe v. Ubani ${ }^{28}$ was an appeal from the dismissed petition in the High Court of the Aba Judicial Division. The election petition arose from an election held on the $12^{\text {th }}$ of December, 1959, to the House of Representatives in respect of the Aba Central Constituency. The 1st Petitioner, who was the first Appellant, claimed that he voted at the election. The 2nd Petitioner, who was the second Appellant, claimed he had a right to vote at the election, but could not vote on the day of the election. Counsel for the petitioners in the Court below and in the appeal, was the defeated candidate of the election, who ought to have been the petitioner in the case.

The petitioners challenged the result of the election on several grounds which where all rejected by the learned trial Judge. Being dissatisfied by the judgement, the petitioner then appealed to the Federal Supreme Court. The appeal centred on the alleged disenfranchisement of a segment of voters in the constituency belonging to a religious sect known as the Seventh Day Adventists, whose rights, it was alleged, were violated. It was alleged that they were subjected to disability or restrictions in that it is contrary to the ethics of their religion to do anything or any manner of work on a Saturday which is their Sabbath day. Thus, many of them for fear of being excommunicated from the Church refrained from going to the polls.

It was contended in the appeal that the political rights of members of this religious group had been violated and this had in effect affected their fundamental human rights.

The Federal Supreme Court therefore considered whether conducting election on worship day was a ground for election petition. The Court held that the conduct of an election on a day set aside as a worship day by a religious sect was not a ground for which an election petition would be sustained under section 6(1)(b) of the Federal Legislative Houses (Disputed Seats) Regulations 1959.

The case of Maikori v. Lere ${ }^{29}$ further demonstrates this legal position. In that case, there was a gubernatorial election on the $14^{\text {th }}$ of December, 1991, in Kaduna State, between Alhaji Mohammed Dabo Lere of the National Republican Convention (NRC) and Professor Ango Abdullahi of the Social Democratic Party (SDP). The candidate for the National Republican Convention (NRC), who was the 2nd respondent in this appeal, defeated his opponent and was declared winner and accordingly returned. Against the background of this declaration, an election petition was filed by the Appellant in this appeal, who curiously was not a candidate in the aforesaid election. The petitioner did not complain against the conduct of the election, neither did he complain against its result. The kernel of his petition was the eligibility of Professor Ango Abdullahi, who was nominated and/or sponsored by the Social Democratic Party (SDP) to contest the Kaduna State Governorship election. It is worthy of note that all the grounds of his complaints were in respect of the primaries and/or run-off election. The Appellant claimed that when he and Professor Ango Abdullahi emerged with the highest votes at the primary election conducted by the Social Democratic Party (SDP) on the $19^{\text {th }}$ of October, 1991, run-off election was held in which he the Appellant emerged the over-all winner. He contended that instead of declaring him the flag bearer of the Social Democratic Party (SDP) to contest the gubernatorial election against Dabo Mohammed Lere, Professor Ango Abdullahi was the one sponsored by his party, the Social Democratic Party (SDP). He therefore prayed the Tribunal to declare that the election and return of Dabo Mohammed Lere were null and void because he and not Professor Dabo Abdullahi was the person who ought to have contested the election against Alhaji Mohammed Dabo Lere on the platform of the Social Democratic Party (SDP). He prayed to be declared validly sponsored and nominated to contest the election which had already been conducted and its result declared. The Tribunal dismissed his claims.

Being dissatisfied with the decision of the tribunal, the Appellant appealed to the Court of Appeal, inviting the Court to consider whether nomination/sponsorship was a valid ground for an election petition. Dismissing the appeal, the court declared:

The crux of Appellant's complaint is that he, rather than Professor Ango Abdullahi

\footnotetext{
${ }^{27}$ Ibid.

28 (1960-1980) LRECN, 154.

${ }^{29}$ (1992) 2 LRECN, 167.
} 
was duly nominated by the Social Democratic Party (SDP) for the governorship election held on the $14^{\text {th }}$ of December 1991 having been declared victorious in the Social Democratic Party (SDP) primaries run-off election. It may well be true that the Appellant was successful in the Social Democratic Party (SDP) primaries run-off. Unquestionably, that complaint was within the domestic domain of the Social Democratic Party (SDP), it cannot ground a petition under section 91 of the State Government (Basic Constitutional and Transitional Provision) Decree 50 of 1991.

An essential reasoning that resonates through these cases is that a petitioner is bound to construct their case upon the substratum cognisable to the CFRN and the Electoral Act as the basis for challenging the outcome of elections. It is however obvious from the cases that the grounds prescribed by the CFRN and the Act, are not exhaustive of the occurrences that could genuinely aggrieve a petitioner, which if not heard would cause injustice. Nevertheless, it may be argued that the need to limit the grounds for challenging election petitions and the even greater need for the courts to adhere to the prescribed ground is justified by the sui generis nature of election petitions. If elections are allowed to be challenged upon any grievance that a petitioner may have, the regime of election petition would become even more complicated than it already is. Furthermore, such would open a floodgate of petitions that election tribunals will be unable to handle within the limited period of operation prescribed for them by law and that enjoined by practicality.

\section{Requirement of Territorial Spread in Governorship and Presidential Elections}

It is worthy of note that without prejudice to the provisions of the CFRN relating to qualifications for and disqualifications from contesting election, sections 133, 134, 178 and 179 of the Constitution makes provisions in relation to the offices of the President and the Governor, the violation of which may give rise to a complaint that any of such office holder has not been duly or validly elected.

Section 133 provides that a candidate for an election to the office of President shall be deemed to have been duly elected to such office where, he/she is the only candidate nominated for the election, if he has a majority of yes votes over no votes cast at the election; and received not less than one quarter of the votes cast at the election in each of at least two thirds of all the states in the federation and the Federal Capital Territory, Abuja. Such a candidate, though unopposed, shall not be declared elected if the candidate fails to secure the requite percentage of votes, it is provided that there shall be fresh nominations. ${ }^{30}$

Combined with section 132(3) (which requires INEC to reopen nominations on the occurrence of events that leaves a single candidate standing for an election), section 133 appears to further prohibit a situation where a candidate is returned elected as the president of the Federation simply because the candidate was unopposed and without the consensus of the people. That being the case, it could be said that sections 132 and 133 are very proactive provision that take account of the antics of politicians, who could use everything within their powers to ensure that no other candidate contests against them, either by inducing them to step down on the eve of the election or compelling them to do the same; either way, the candidate would have prevented an election from taking place. The last (2019) general elections in Nigeria underscores the perchance of politicians throwing their hat in the ring only with the intention of bargaining with their candidature and stepping down for another candidate just in time before the election.

Section 134(1) deals with a situation where there are two candidates. The section requires the successful candidate to have scored the majority of votes cast at the election, and must have score not less than one quarter of the votes cast at the election in each of at least two thirds of all the states in the federation and the Federal Capital Territory, Abuja. Section 134(2) repeats the provision of subsection (1) for situations where there re more than two candidates. Subsection (3) however covers the event that no winner emerges from the ballot held under subsection (2) - that is, where one of the three or more candidates is able to score the highest votes and meet the territorial requirements - by providing for a second ballot at which the only candidates shall be the candidate who scored the highest number of votes at the first ballot an the one among the remaining candidates who has a majority of votes in the highest number of states. But where there are more than one candidate with a majority of votes in the highest number of states, the candidate among them with the highest total of votes cast at the election shall be the second candidate for the election. It is provided in subsection (4) that the INEC should within seven days of the result of the election held under the said subsection (3) In which no candidate was duly elected, arrange for an election between the two candidates, and that a candidate of such election shall be

${ }^{30}$ Section 133(a) and (b) of the Constitution 
deemed to have been duly elected to the office of President if:

(a) He has a majority of votes cast at the election; and

(b) He has not less than one quarter of the votes cast at the election in each of at least two thirds of all the states in the federation and the Federal Capital Territory, Abuja.

By subsection (5) if no candidate emerges of the two of them under subsection (4), the INEC is further mandated to within seven days of the result of the election arrange for another election between the two candidates to which the subject relates and deemed to have been duly elected to the office of President, if he has a majority of the votes cast at the election".

With respect to the office of the governor of a state, section 179 of the CFRN, which deals with election to the office of a governor, needs not delay us here as it merely replicates the provisions of sections 133 and 134 of the CFRN mutatis mutandis, and is addressed later in this work.

The provisions of sections $133,134,178$ and 179 of the Constitution appear innocuous, ordinarily, as they relate to territorial spread of votes for a presidential or gubernatorial candidate. However, it could be the major hurdle in an election petition. This is more so, as the number of states of the Nigerian Federation or the number of local governments in a state are not divisible by three, and the result of an election as the margin to win is predicated on the mathematics in relation to the legal interpretation of the constitutional requirements.

This was aptly demonstrated in the landmark case of Awolowo $v$ Shagari ${ }^{31}$ which arose from a similar provision of the Electoral Decree No. 73 of 1977. As is the present Electoral Act, one of the hurdles before a successful candidate in elections under that Decree, was that the winner must score the majority of votes cast in the election and must score not less than one quarter of the votes cast in the election in each of at least two thirds of all the then nineteen states of the federation. Chief Obafemi Awolowo, the Petitioner/Appellant, scored at total of Four Million, Nine Hundred and Sixteen Thousand, Six Hundred and Fifty One $(4,916,651)$ votes and also scored at least twenty five percent of votes cast in six states of the federation. Alhaji Shehu Shagari scored the highest number of votes throughout the country. He scored a total of Five Million, Six Hundred and Eighty Eight Thousand, Eight Hundred and Fifty Seven $(5,688,8520)$ votes. Alhaji Shehu Shagaria also scored at least twenty five percent of votes cast in each of twelve states, viz: Bauchi, Bendel, Benue, Borno, Cross river, Gongola, Kaduna, Kwara, Niger, Plateau, Sokoto and Rivers. Worthy of mention at this juncture, is that Kano was the thirteenth state where Alhaji Shehu Shagari scored a total of Two Hundred and Forty Three Thousand, Four Hundred and Twenty Three $(243,423)$ votes out of One Million, Two Hundred and Twenty Six Thousand, Seven Hundred and Sixty Three $(1,226,763)$ votes returned in state. Ipso facto, the score of Two Hundred and Forty Three Thousand, Four Hundred and Twenty Three $(243,423)$ represented $19.94 \%$ of the votes cast in Kano state.

Though having the majority of votes, Shagari did not score the requisite one-quarter of votes cast in two-third states. He fell short of one state, given he won in twelve states, which is mathematically not two-third of nineteen. This created constitutional and jurisprudential dilemma for the courts, giving that a state cannot be fractionalized mathematically. In its decision upholding the election, the trial tribunal declared:

As the dominant requirement in the election is the number of votes cast in each state, two third states would be synonymous with two thirds of the total votes cast in that state and not the physical or territorial area of such state. It is not disputed that the first respondent, Alhaji Shehu Shagari, scored twenty five percent of the total votes cast in twelve states .... But in order to succeed, he must score in addition twenty five percent of the total votes cast in the remaining "two third state". This might be in Kano State where the first respondent scored $19.94 \%$ of the total votes cast in that state which is $1,220,763$. The question therefore is: What then is the total votes cast in two thirds of Kano State? The obvious answer is 813,842 . A quarter or twenty five percent of those votes will then be 203,460.5 votes. According to exhibit T2, the total votes scored by the First Respondent, Alhaji Shehu Shagari, are 243,423 cast in two-thirds of Kano State. In the circumstance, we are satisfied that the first respondent has satisfied the provisions of section 34 A (1) c (i) and (ii) of the Decree, and we therefore hold that he was duly returned by the Third Respondent, F.L.O. Menkiti, the Returning Officer, Presidential Election, as duly elected President of the Federal Republic of Nigeria.

${ }^{31}$ (1979) NSCC 87. 
The Supreme Court consequently affirmed the judgment of the presidential election petition tribunal. Fatai-Williams CJN, in the leading judgment, agreed with the Tribunal that Shagari satisfied the geographical requirements but the court observed that Shagari scored by far the highest number of votes and achieved more geographical spread than all the candidates that contested against him. Based on this observation, the court declared (and this is the better view than the definition of two-third of 19 States):

In view of the above, there is no doubt that even if we found that there had been non-compliance with the said provisions, we would have invoked the provisions of the Decree and held that the election, which in the present context means the election to the office of the president was conducted substantially in accordance with the provisions of section 34 (a)(i) (c)(ii) which is with Part II of the Decree.

By reason of this provisions is that an election shall not be invalidated by reason of non-compliance with the relevant part of the Decree if it appeared to the tribunal having recognizance of the question that the election was conducted substantially in accordance with the provisions of the Decree and that the non-compliance did not affect the result of the election.

It must be observed that notable legal scholars have been very critical of the Supreme Court's decision in the case of Awolowo v. Shagari. ${ }^{32}$ The popular view appears to be that the case was not decided on the strict application of the criteria set by the Electoral Decree No 73 of 1977, as amended, but on the basis of political expediency at the time. This appears to be a correct view of the decision because Fatai-Williams CJN, in his leading judgment, even admitted that Alhaji Shehu Shagari, the first respondent did not meet the territorial spread required by the extant law, when he admitted that "the percentage of 19.94 scored by the first respondent in respect of the votes cast in the whole of Kano falls short of $25 \%$ by only $5.06 \%$."

Indeed, the decision of the Supreme Court in this case culminated in many questions than answers, and these questions influenced the draftsmen of the CFRN in the provisions of sections 133,134,178and 179 of the CFRN. These provisions attempt to resolve the unanswered questions in the case of Awolowo v. Shagari, ${ }^{33}$ whereas section 133 of the CFRN contemplates election of a single presidential candidate as encapsulated on the side note to the section.

Thus, though it is provided in section 133(a) and (b) of the CFRN that a single candidate can only be deemed to be duly elected if he has majority of 'Yes' vote over 'No' vote cast at the election and should have not less than one-quarter of the vote cast at the election in each of at least two thirds of all the state of the Nigerian federation and the Federal Capital Territory, Abuja. The mischief in the provision as seen in Awolowo v. Shagari ${ }^{34}$ was cured by the second limb of section 133(b) of the Constitution, which specifically provides for a scenario where a single presidential candidate fails to meet the mandatory requirement in section 133(a) and (b) of the Constitution. It states categorically that the failure of a single presidential candidate fails to meet the mandatory requirement as encapsulated in section 133(a) and (b) of the Constitution, means that the single presidential candidate fails to be elected and consequently there shall be fresh nominations.

It is pertinent to observe that without prejudice to the provisions of section 133, section 134(1)(a) and (b) of the CFRN (earlier mentioned) contemplate the existence of two presidential candidates and states that the candidate should be deemed to have been elected if he has majority of votes cast at the election and not less than one quarter of the votes cast at the election in each of at least two thirds of all states of the Nigerian Federation and the Federal Capital Territory, Abuja. Section 134(2)(a) and (b) of the Constitution contemplates the existence of more than two presidential candidates and provide that a candidate shall be deemed to have been duly elected if he has the highest number of votes cast at the election and not less than one quarter of the votes cast at the election in each of at least two third of all the states in Nigerian Federation and the Federal Capital Territory, Abuja. It is worthy of note that as an act of good draftsmanship, the draftsmen of the Constitution also genuinely contemplated a possible default of a presidential candidate duly elected in accordance with section 134(2)(a)(b) of the Constitution and prescribe a second election in tandem with section 134(4) of the Constitution. This is provided for in section 134(3)(a) and (b) of the Constitution and it states that in the second election, the only candidate shall be the candidate who scored the highest number of votes at any election held in accordance with section 134(2) of the Constitution. In addition, the other two candidates shall be one among the remaining candidates who has a majority of votes in the highest number of states. If, however, there are more than one

\footnotetext{
32 (1979) 12 NSCC 87

33 (1979) 12 NSCC 87.

${ }^{34}$ Ibid.
} 
candidate with a majority of votes in the highest number of states, the candidates among them with the highest total of votes cast at the election shall be the second candidate for the election. ${ }^{35}$ Section 134(4) of the Constitution, states that in view of the aforesaid default of a candidate being duly elected, the Independent National Electoral Commission shall within seven days of the result of the election in default arrange for an election between the two candidates. In tandem with section 134(4)(a) and (b) of the Constitution, a presidential candidate in this election shall be deemed to have been duly elected if he has a majority of votes at the election and not less than one quarter of the votes cast at the election in each of at least two-thirds of all the states of the Nigerian federation and the Federal Capital Territory, Abuja.

It is submitted that to ensure a free, fair and credible presidential election with territorial spread, the Constitution contemplates first, second and third elections when necessary in a presidential election with more than two candidates as provided for in section 134(2)(a) and (b), 3(a) and (b) and (4)(a) and (b) of the Constitution. It is of utmost significance to state that section 134(5) of the Constitution proffers a constitutional solution to any possible constitutional stalemate that could be occasioned by a scenario where no candidate in a presidential election is able to meet the strict constitutional requirement of having the majority of votes cast at the election and less than one-quarter of the votes cast at the election in each of at least two thirds of all the states of the Nigerian Federation and the Federal Capital Territory, Abuja, in the first, second and third elections, respectively. To that extent section 134(5) of the Constitution provides that after the first second and third elections and in default of a candidate duly elected, the Independent National Electoral Commission shall within seven days of the result of the election, ${ }^{36}$ arrange for another election between the two candidates, and a candidate at such election shall be deemed to have been duly elected to the office of president if he has a majority of the votes cast at the election, without more.

The draftsmen of the Constitution also made copious provisions in an election to the office of Governor, with constitutional solution in case of a scenario that gravitates towards a constitutional stalemate. Section 179(1)(a) and (b) of the Constitution contemplates a setting where there is a single candidate contesting to the office of Governor. It is required that such a single candidate can only be deemed to have been duly elected to the office of Governor if he has majority of 'Yes' votes over 'No' votes cast at the election and has not less than one quarter of the votes cast at the election in each of at least two third of all the local government areas in the state. The constitutional provision further stipulates that where the sole candidate fails to be elected in tandem with section 179(1)(a)(b), of the Constitution, there shall be fresh nominations. In the second possible scenario, where there are two or more candidates for an election to the office of governor of a state, a candidate shall be deemed to have been duly elected if he has the highest number of votes cast at the election and has not less than one-quarter of all the votes cast in each of at least two thirds of all the local government areas in the state. Section 179(3)(a) and (b) of Constitution contemplates a scenario where there is default of a candidate duly elected in tandem with section 179(2)(a)(b) of the Constitution. It provides therefore for a second election, where the only candidate shall be the candidate who secured the highest number of votes cast at the election and one among the remaining candidates who secured majority of votes in the highest number of local government areas in the state. However, in a situation where there are more than one candidate with a majority of votes in the highest number of local government areas, the candidate among them with the next highest total of votes cast at the election shall be the second candidate. In pursuant of the second election, the Independent National Electoral Commission shall within seven days of the result of the first election arrange for an election between the two candidates, and a candidate shall be deemed to have been duly elected to the office of governor of a state if he has a majority of votes cast at the election and has not less than one quarter of the votes cast at the election in each of at least two thirds of all the local government areas in the states.

In the possible scenario where no candidate is elected in tandem with section 179(4)(a) and (b) of the Constitution, section 179(5) of the Constitution prescribed a panacea to such imminent constitutional stalemate. It prescribes that the Independent National Electoral Commission shall within seven days of the result of the second election arrange for another election between the hitherto existing two candidates, and a candidate at such election shall be deemed to have been duly elected to the office of Governor of a state if he has a majority of the votes cast at the election, without more.

\section{Conclusion}

This article has sought to highlight certain recurrent features of elections in Nigeria. It is almost certain to predict that over 90 percent of elections in Nigeria will end up being contested by way of election petition on the basis

\footnotetext{
${ }^{35}$ The second election cognizable under section 134 (3) (a) and (b) of the Constitution of the Federal Republic of Nigeria 1999 (as amended).

${ }^{36}$ This refers to the election held under section 134(4), of the Constitution of the Federal Republic of Nigeria 1999 (as amended).
} 
that the candidate returned as the winner was not validly elected to the office. As this article has shown, the grounds for contesting the validity of an electoral return are not left to nebulosity and thus are not capable of being expanded or constricted by the ingenuity of counsel or the prerogative of the judge.

We have shown that the grounds for questioning elections in Nigeria are quite clearly stated in the relevant provisions of the CFRN -239(11)(a) and section 285(1)(a) and (2) - and the Electoral Act - 138(1)(a)(b)(c) and (d). Beyond these, the courts are not entitled to look to no other piece of legislation. It is submitted that a petitioner can predicate his petition under the grounds stipulated in the Electoral Act or under the Constitution or both.

As we have equally shown the grounds for election petitions being similar to the foundation of a house upon which other structures of the house are predicated, the averments in the pleadings and the reliefs sought in the petition must be predicated on the grounds for the petition. This position of law was echoed by the Supreme Court in the case of Oshiomole v. Airhiavbere ${ }^{37}$ where the Court emphatically stated that:

Parties are bound to their pleadings. That is to say, if pleadings are to be of any use, parties must be held bound by them. In the instant case, on the state of the petition, the first respondent's case was that the election was invalid by reason of corrupt practices and not that the appellant was not qualified to contest an election. The petitioners were bound by their case as pleaded. Consequently, the tribunal had no jurisdiction to hear and determine the qualification and non-qualification of the appellant, since there was no ground from which such issue could be formulated. A consideration of the non-qualification of the appellant would amount to going outside the pleadings and that would be wrong.

In the final analysis, it is the duty of the petitioner to locate their complaint within the prescribed grounds for questioning the validity of an election, given that election petition judges exercise very strict jurisdiction that hardly yields to the discretion of the judges or manipulations by counsel. It is thus essential for a would-be petitioner to seriously consider their intended ground for seeking to question an election in the light of the relevant provisions of the CRFN and the Electoral Act, so as to avoid a situation where the petitioner merely engages in worthless judicial exercise from the start at the expense of both their own resources and that of the tax payers.

\section{Copyrights}

Copyright for this article is retained by the author(s), with first publication rights granted to the journal.

This is an open-access article distributed under the terms and conditions of the Creative Commons Attribution license (http://creativecommons.org/licenses/by/4.0/).

${ }^{37}$ (2013) 7 NWLR, pt. 1353, 376, 378. 